\title{
触 New Disease Reports \\ First reports of Lettuce big-vein associated virus and Mirafiori lettuce big-vein virus infecting lettuce in Saudi Arabia
}

\author{
M.A. AL-Saleh ${ }^{1}$, I.M. AL-Shahwan ${ }^{1}$, M.A. Amer ${ }^{1}$, M.T. Shakeel ${ }^{1}$, M. Umar ${ }^{1}$, O.A. Abdalla ${ }^{1}$, C.E. Efthimiou ${ }^{2}$ and N.I. Katis $^{2}$ \\ ${ }^{1}$ Plant Protection Department, College of Food and Agriculture Sciences, King Saud University, PO Box 2460, Riyadh \\ 11451, Saudi Arabia; ${ }^{2}$ Aristotle University of Thessaloniki, School of Agriculture, Forestry and Natural Environment, Faculty \\ of Agriculture, Plant Pathology Lab, PO Box 269, Thessaloniki 54124. Greece
}

*E-mail: malsaleh@ksu.edu.sa

Received: 01 Dec 2014. Published: 01 Feb 2015. Keywords: Lettuce big vein disease, sequence, LBVV, MiLBVV

Lettuce (Lactuca sativa) is a common vegetable in Saudi Arabia, being cultivated on more than 4000 ha either in open fields or in greenhouses. In March 2014, field lettuce crops were surveyed in the Riyadh region and around $40 \%$ of plants were observed to have virus-like symptoms including vein clearing, stunting, deformed leaves and thickening of the main veins (Fig. 1). These symptoms resemble those caused by Lettuce big-vein disease (LBVD), an important disease of lettuce worldwide. Two viruses are associated with LBVD, Lettuce big-vein associated virus (LBVaV, Varicosavirus) and Mirafiori lettuce big-vein virus (MiLBVV, Ophiovirus) which are transmitted by the soil fungus Olpidium brassicae (Verbeek et al. 2013). Nineteen samples (17 symptom-bearing and two symptomless) were collected from four fields and total RNA was extracted (Chatzinasiou $e$ al. 2010). The extracted RNA was subjected to a multiplex reverse transcription (RT) PCR for the simultaneous detection of LBVaV and MiLBVV, using specific primers amplifying 296 and 469 bp fragments of their CP genes, respectively (Navarro et al., 2004). The presence of $O$. brassicae was confirmed in the rootlets of all the symptomatic lettuce plants using light microscopy (Rochon, 2009). The results showed that 16 of the 17 lettuce samples showing symptoms were infected with LBVaV, nine with MiLBVV and eight with both LBVaV and MiLBVV. The two symptomless samples were found to be negative for both viruses. Two PCR products from each virus extracted from different plants were randomly selected for direct sequencing. The sequences were submitted to GenBank (Accession Nos.KJ701037, KJ701038, KJ701039 and KJ701040) and analysed using BLAST. Both sequences of LBVaV had $98 \%$ nucleotide (100\% amino acid) identity with a sequence from Spain (AY366413) and $99 \%$ nucleotide (100\% aa) identity with sequence from Japan (AB190528).
The two MiLBVV sequences showed 98\% (99\% aa) and 99\% nucleotide identity (99\% aa) with an isolate from Spain (AY366418). To our knowledge, this is the first report of the occurrence of LBVD-associated viruses $\mathrm{LBVaV}$ and MiLBVV in Saudi Arabia. Further surveys for monitoring the incidence and distribution of both LBVaV and MiLBVV in Saudi Arabia are in progress.

\section{References}

Chatzinasiou E, Dovas CI, Papanastassopoulou M, Georgiadis M, Psychas V, Bouzalas I, Koumbati M, Koptopoulos G, Papadopoulos O, 2010. Assessment of bluetongue viraemia in sheep by real-time PCR and correlation with viral infectivity. Journal of Virological Methods 169, 305-315. http://dx.doi.org/10.1016/j.jviromet.2010.07.033

Navarro JA, Botella F, Maruhenda A, Sastre P, Sánchez-Pina MA, Pallas V, 2004. Comparative infection progress analysis of Lettuce big-vein virus and Mirafiori lettuce virus in lettuce crops by developed molecular diagnosis techniques. Phytopathology 94, 470-477. http://dx.doi.org/10.1094/PHYTO.2004.94.5.470

Rochon DA, 2009. Fungal Transmission of Plant Viruses. Current Protocols in Microbiology 12, 16B-4, 1-17.

http://dx.doi.org/10.1002/9780471729259.mc16b04s12

Verbeek M, Dullemans AM, van Bekkum PJ, van der Vlugt RAA, 2013. Evidence for Lettuce big-vein associated virus as the causal agent of a syndrome of necrotic rings and spots in lettuce. Plant Pathology 62, 444-451. http://dx.doi.org/10.1111/j.1365-3059.2012.02645.x

\section{Figure 1}

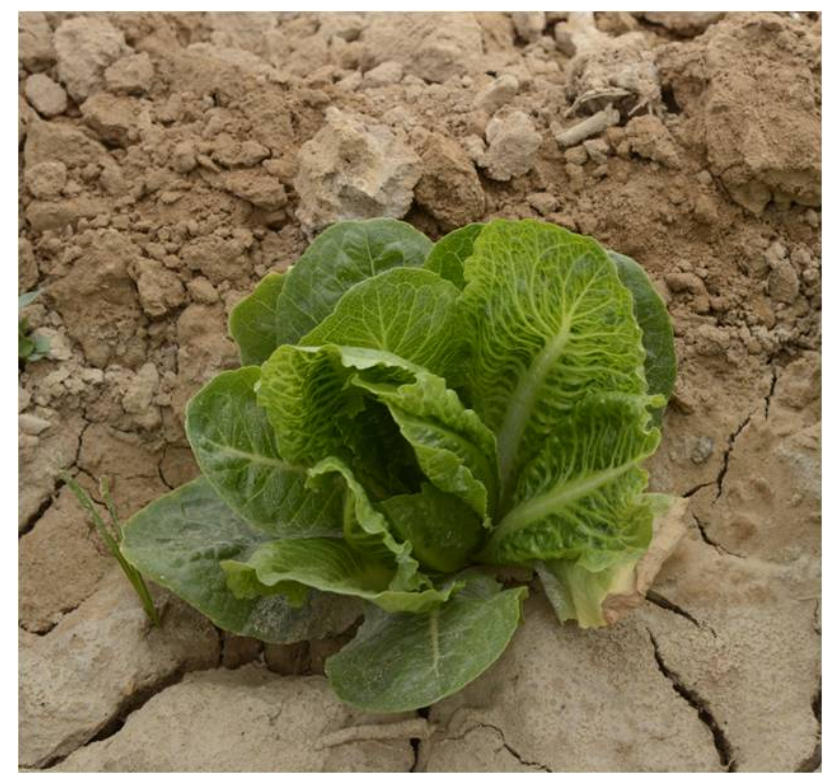

To cite this report: AL-Saleh MA, AL-Shahwan IM, Amer MA, Shakeel MT, Umar M, Abdalla OA, Efthimiou CE, Katis NI, 2015. First reports of Lettuce big-vein associated virus and Mirafiori lettuce big-vein virus infecting lettuce in Saudi Arabia. New Disease Reports 31 , 2. http://dx.doi.org/10.5197/j.2044-0588.2015.031.002 